Ltd., 21 Bruton Street, London, W.1, who recently exhibited in London examples of moulded valveholders and other components in polytetrafluoro. ethylene.

\section{Pure Science and Industrial Development}

IN an address, "Pure Science, Fertile Source of Industrial Progress", on receiving from the Société pour l'Encouragement de l'Industrie Nationale the medal of the Grand Prix du Marquis d'Argenteuil for 1947, Prof. L. de Broglie gave a brilliant review of the contribution of research in fundamental physics to the progress of industry, in which he referred particularly to the achievements of such French physicists as D. Papin, S. Carnot, Ampère and M. Deprez. He also pleaded for the vigorous prosecution both of the investigation of the laws of Nature without reference to their application, and of industrial and technical research directed towards the utilization of scientific knowledge for the improvement of human welfare. Prof. de Broglie drew his illustrations from the fields of heat, electricity, wave mechanics, relativity and nuclear physics, indicating how discoveries and investigations which have appeared incredibly remote from practical life have yet in due course made most important contributions to industrial progress.

\section{Sugar Research Foundation Prize}

ENTRIES are invited for the 1949 fourth intermediate prize award of 5,000 dollars offered by the Sugar Research Foundation. The award will be given for discoveries in the chemistry, physiology or technological application of carbohydrates which contribute to an understanding of the functions of sugar (sucrose) or to its practical utilization. The first of these awards (1946) was made to Drs. W. Z. Hassid, M. Doudoroff and H. A. Barker, of the University of California, Berkeley, for research leading to the enzymatic synthesis of sucrose; the second (1947) went to Dr. Carl F. Cori, professor of biochemistry, Washington University, St. Louis, Missouri, for research on problems of carbohydrate metabolism in the animal body; the third (1948) to Dr. Leslie F. Wiggins, University of Birmingham, for chemical studies of the sucrose molecule and transformations which may make sucrose a valuable raw material in the chemical industries. Winners of these intermediate annual awards are eligible for the Grand Prize of 25,000 dollars to be given in 1950 for the most important work during the five preceding years. Further particulars can be obtained from the Executive Secretary, National Science Fund, National Academy of Sciences, 2101 Constitution Avenue, N.W., Washington 25, D.C., to whom entries must be submitted by January 1, 1949.

\section{Beilby Memorial Awards}

From the interest derived from the invested capitzl of the Sir George Beilby Memorial Fund, at intervals to be determined by the administrators representing the Royal Institute of Chemistry, the Society of Chemical Industry, and the Institute of Metals, awards are made to British investigators in science to mark appreciation of records of distinguished work. Preference is given to investigations relating to the special interests of Sir George Beilby, including problems connected with fuel economy, chemical engineering and metallurgy, and awards are made generally to younger men who have done original independent work of exceptional merit over a period of years. The administrators-the presidents, honorary treasurers and secretaries of the three participating institutions--will be glad to have their attention directed to outstanding work of the nature indicated, not later than December 31, 1948. Communications should be addressed to the Convener, Sir George Beilby Memorial Fund, Royal Institute of Chemistry, 30 Russell Square, London, W.C.1.

\section{"Changing Aspects of Nutrition"}

AN article under this title in Nature, October 2, pp. 543 and 544, dealt with the proceedings of a discussion on September 9 in Section I (Physiology) of the British Association. In the report of Dr. J. W. Howie's contribution, reference is made to a "protein rice concentrate"; this should read "protein-rich concentrate". Ew'es fed this concentrate as a supplement to pasture grazing showed, over a period of two years observation, no difference in fæces worm. egg counts from similar ewes grazed on the same pasture but not fed concentrate. Lambs born of the ewes and fed the same diet as their mothers, however, showed a marked difference in worm burden during a year's observation, the lambs given concentrate having significantly fewer worm eggs in the fæces. The account of Dr. Howie's second experiment, in which diet was shown to influence the resistance of mice to experimental tuberculosis, may have suggested that the higher protein in the better diet was established as the cause of the superior resistance. Dr. Howie wishes to make it clear that he has not yet examined this possibility, and that other important differences between the diets must be taken into account.

\section{Announcements}

The Meldola Medal is the gift of the Society of Maccabæans and is normally awarded annually. The next award will be made early in 1949 to the chemist who, being a British subject and less than thirty years of age on December 31, 1948, shows the most promise, as indicated by his or her published chemical work brought to the notice of the Council of the Royal Institute of Chemistry before December 31, 1948. Communications should be addressed to the President, Royal Institute of Chemistry, 30 Russell Square, London, W.C.1, the envelope being marked "Meldola Medal".

A symposium on the "Applications of Electronics to Research and Industry" has been arranged by the Electronics Group of the Scientific Instrument Manu. facturers' Association. It will be held at the Caxton Hall, London, during November 18 and 19.

A FUND for the encouragement of the gliding and soaring movement is being raised as a tribute to the late Robert Kronfeld, who was killed while testing a tailless glider early this year. A committee has been formed to make the appeal and receive subscriptions, which should be sent to Mr. Lawrence Wingfield, c/o Royal Aeronautical Society, 4 Hamilton Place, W.1, marked Kronfeld Memorial Fund.

A HALF-YEARLY list of botanical papers printed in India, Pakistan, Burma, Ceylon, Siam, Malaya and Indonesia will be published by the Botanical Society of Bengal in the Society's Bulletin issued in April and October every year. Authors are requested to send their reprints to the Honorary Secretary, Botanical Society of Bengal, 35 Ballygunge Circular Road, Calcutta 13. 